\title{
Comparaison between MPPT P\&O and MPPT Fuzzy Controls in Optimizing the Photovoltaic Generator
}

\author{
Messaouda AZZOUZI \\ Faculty of Sciences and Technology \\ Ziane Achour University of Djelfa \\ Djelfa, Algeria
}

\begin{abstract}
This paper presents a comparative study between two control methods in order to optimize the efficiency of the solar generator. The simulation had been established by using Matlab/Simulink software to apply the MPPT P\&O and MPPT Fuzzy controls on this system which is supplied through a Boost converter.Many results have been illustrated under standard and then variable weather conditions such as the illumination and the temperature. The voltage and the power of the panel and the battery as well as the duty cycle are well presented and analyzed for the two control methods. The obtained results show the effectiveness of MPPT Fuzzy controller in optimizing the PV generator. These results can encourage the use of this control strategy on solar panels in real time to optimize their yield.
\end{abstract}

Keywords-solar energy; photovoltaic; PV; MPPT; P\&O; Boost converter; fuzzy; optimization.

\section{INTRODUCTION}

The photovoltaic solar energy is among the renewable energies which have the largest development potential. Photovoltaic (PV) generator is based on the smallest unit which is the solar cell. This last is PN junction that generates electricity when it is exposed to light [1].

There are several circuit models for a PV cell but the Single-Diode model is most used because it is the simplified one. Fig. 1 shows a Single-Diode equivalent circuit of solar cell [3] [4].

The output current of the solar cell is given by:

$$
\mathrm{I}=\mathrm{I} \pi \eta-\mathrm{I} \delta-\mathrm{IP} \pi
$$

By considering the electrical characteristics of the $\mathrm{PN}$ junction, this current can be given by:

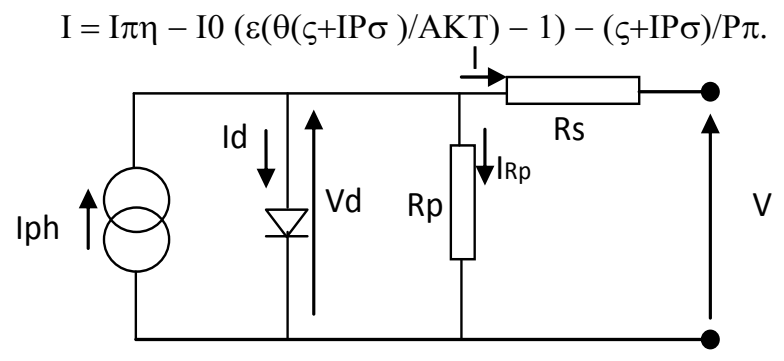

Figure 1. Single-Diode equivalent circuit model of solar cell

When we replace the term $\varsigma_{\mathrm{T}}=\mathrm{KT} / \theta$, we find:

$$
\mathrm{I}=\mathrm{I} \pi \eta \mathrm{I} 0[(\varepsilon(\varsigma+\mathrm{IP} \sigma) / \mathrm{A} \varsigma \mathrm{T}-1)] .
$$

The output voltage of the cell becomes:

$$
\varsigma=-\mathrm{IP} \sigma+(\mathrm{AKT} / \theta) \lambda v((\mathrm{I} \pi \eta-\mathrm{I}+\mathrm{I} 0) / \mathrm{I} 0) .
$$

The output power of the solar cell is calculated as:

$$
\Pi=\mathrm{I} . \varsigma \text {. }
$$

Where:

$$
\begin{aligned}
& \mathrm{P} \sigma: \text { series resistance } \\
& \mathrm{P} \pi \text { : parallel resistance } \\
& \mathrm{I} \pi \eta \text { : short circuit current } \\
& \mathrm{I} \delta \text { : current of the diode } \\
& \mathrm{IP} \pi \text { : current of the parallel resistor } \mathrm{P} \pi \\
& \mathrm{I} \text { : output current and of the solar cell } \\
& \varsigma: \text { output voltage of the solar cell } \\
& \mathrm{I}_{0}: \text { reverse saturation current of the diode } \\
& \theta \text { : charge of the electron } \\
& \text { A: diode ideality factor } \\
& \mathrm{K}: \text { Boltzmann constant } \\
& \mathrm{T}: \text { temperature in }{ }^{\circ} \mathrm{K}
\end{aligned}
$$

\section{MAXIMUM POWER POINT TRACKING}

A dynamic tracking method is necessary to extract the maximum power from the PV cells [3]. Many researches has been developed concerning the different algorithms for the maximum power point tracking (MPPT) considering the variations of the system parameters and/or weather changes [2] [6], such as perturb and observe method, open and short circuit method, incremental conductance algorithm, fussy logic and artificial neural network. The block diagram in Fig.2 presents a PV generator with MPPT [5] [11]. The load or the battery can be charged from a PV panel using a MPPT circuit with a specific controller to track the peak power generated by the PV panel.

Other protection devices can be added. The control circuit takes voltage and current feedback from the battery, and generates the duty cycle $\mathrm{D}$, This last defines the output voltage of the Boost converter [10] [13]. 


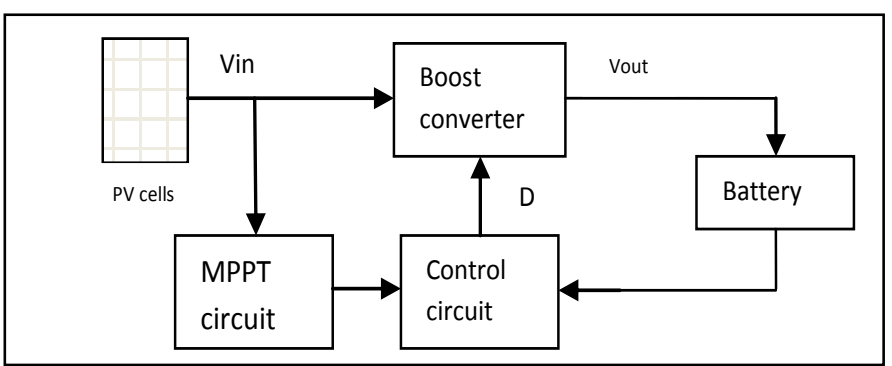

Figure 2. Schematic PV generator with MPPT

\section{A. $P \& O$ algorithm}

The chart in Fig. 3 demonstrates the principle of the Pertub and Observe (P\&O) algorithm [5] [7]. This last has been largely used because it is easy to implement, it is based on the perturbation incrementing or decrementing the voltage Vref, or the current Iref with observing the result of this disturbance on the measured power $(\mathrm{P}=\mathrm{VI})$ [8] [12].

\section{B. Fuzzy logic}

This method uses fuzzy logic to have a faster controller response and to increase system stability once reached the MPP [1]. The tracking of the MPP will be divided into two phases: the first phase is of tough research, with a significant step to improve the response of the MPPT controller, the second one is the fine phase where the step is very small, thus ensuring the system stability and decrease the maximum oscillations around the MPP. This feature of the fuzzy controller demonstrates its effectiveness and makes it among the best MPP tracking devices [9]. The fuzzy controller consists of three blocks: the fuzzification of input variables which is performed in the first block, it allows the passage from the real domain to fuzzy domain. The second block is devoted to inference rules, while the last block is the defuzzification for returning to the real domain. This last operation uses the center of mass to determine the value of the output. Fig. 4 shows the basic structure of the used MPPT Fuzzy controller [9].

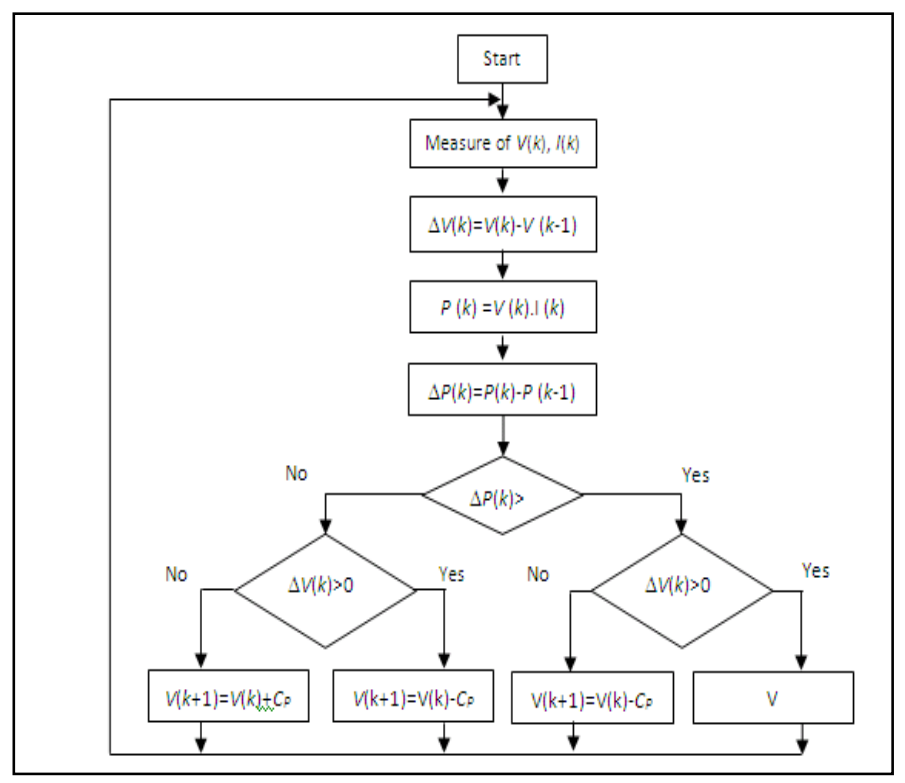

Figure 3. Chart of the algorithm $\mathrm{P} \& \mathrm{O}$ (CP: step width of the disturbance)

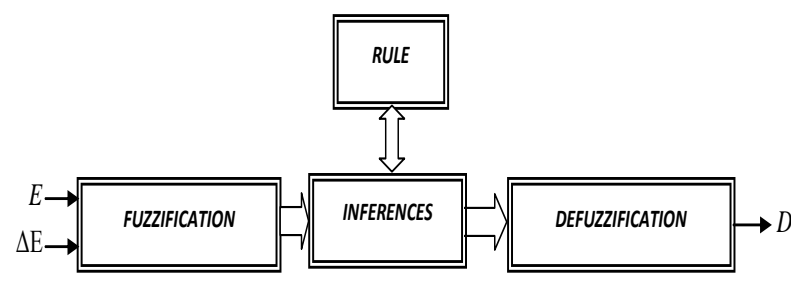

Figure 4. Basic structure of MPPT fuzzy controller

TABLE I. INFERENCES TABLE OF THE FUZZY CONTROLLER

\begin{tabular}{|c|l|l|l|l|l|l|}
\hline$\downarrow \mathbf{E}$ & \multicolumn{1}{|c|}{$\begin{array}{l}\mathbf{\rightarrow} \\
\text { NB }\end{array}$} & NG & NP & EZ & PP & PG \\
\hline NS & EZ & EZ & PP & PP & PP \\
\hline ZE & PP & EZ & EZ & EZ & NP \\
\hline PS & NP & NS & NS & EZ & EZ \\
\hline PB & NG & NG & NG & EZ & EZ \\
\hline
\end{tabular}

The proposed MPPT fuzzy controller has two inputs and one output. The two inputs are the error $\mathrm{E}$ and the error variation $\otimes \mathrm{E}$ taken at each sampling step $\kappa$. These two variables are defined by:

$$
\begin{aligned}
& \mathrm{E}(\kappa)=(\Pi \pi \eta(\kappa)-\Pi \pi \eta(\kappa-1)) /(\varsigma \pi \eta(\kappa)-\varsigma \pi \eta(\kappa-1)(6) \\
& \otimes \mathrm{E}(\kappa)=\mathrm{E}(\kappa)-\mathrm{E}(\kappa-1)
\end{aligned}
$$

Where:

$\Pi_{\pi \eta}:$ Instantaneous power of the PV generator;

$\varsigma_{\pi n}$ : Instantaneous voltage of the PV generator.

The value of $\mathrm{E}(\mathrm{\kappa})$ shows the position of the operating point for the load at time $\mathrm{k}$ relative to the maximum power point. The value of $\otimes \mathrm{E}(\kappa)$ expresses the direction of movement of this point [1].

The method chosen for inference in our work is that of Mamdani, and for the defuzzification we used the center of gravity method for calculating the output $\Delta$. The duty cycle of DC/DC converter is given by:

$$
\Delta=\sum_{\mathrm{j}=1}^{\mathrm{n}} \text { ? }(\mathrm{Dj})-\mathrm{Dj} / \sum_{\mathrm{j}=1}^{\mathrm{n}} \text { ?(Dj) }
$$

The inference rules can make the right decision for output $\mathrm{D}$ from the values of $\mathrm{E}$ and $\Delta \mathrm{E}$. We chose the rules presented in Table.I.

\section{OPERATION IN STANDARD CONDITIONS}

The figures below allow us to visualize the variation of the duty cycle and the powers of the module and the battery as the voltages of the module and the battery with $\mathrm{P} \& \mathrm{O}$ and then fuzzy controllers in standard atmospheric conditions $\left(1000 \mathrm{~W} / \mathrm{m}^{2}, 25^{\circ} \mathrm{C}\right)[14]$. 

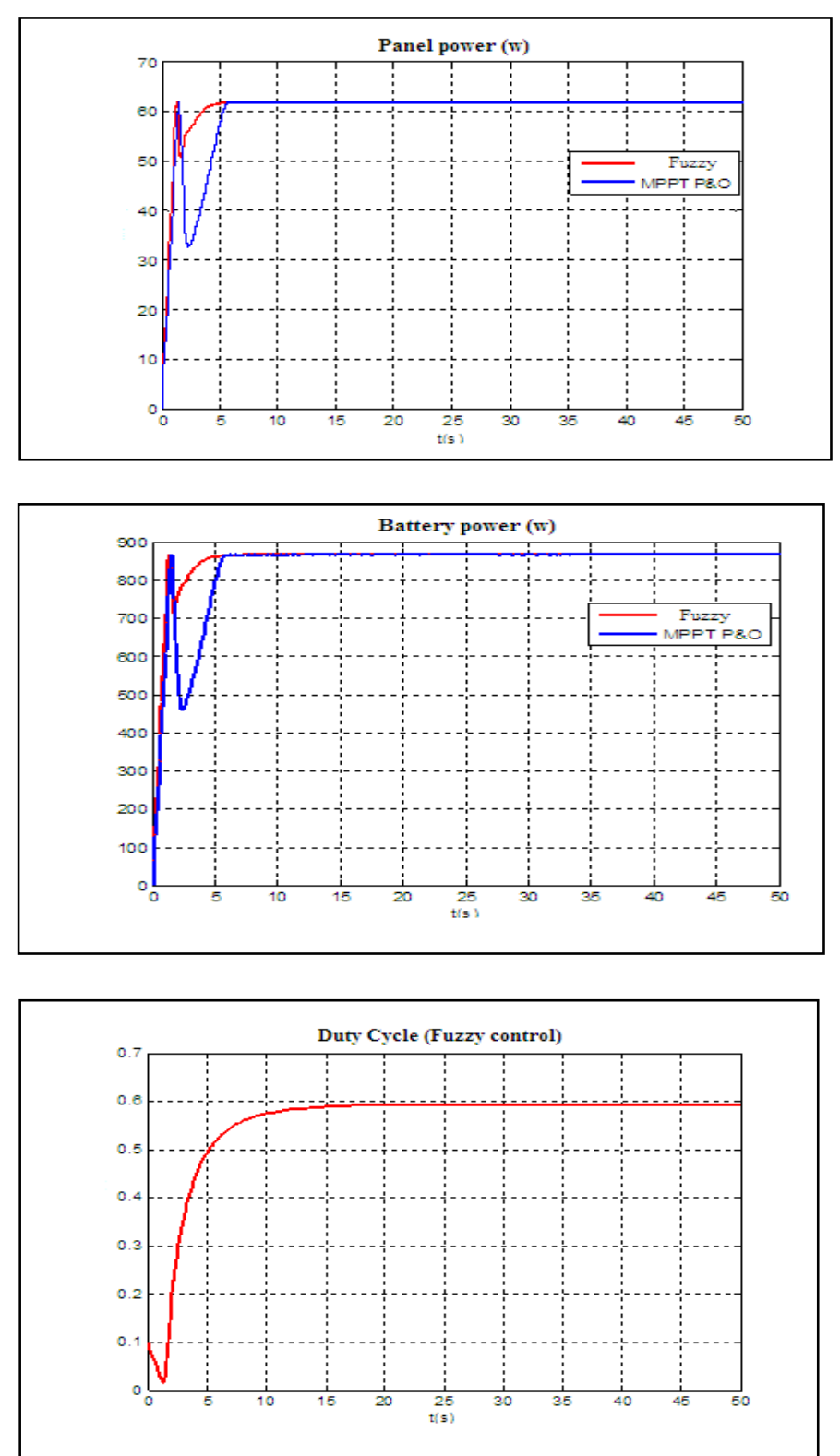

Figure 5. Power variation of the module, and battery and duty cycle $\mathrm{D}$ for both controllers and under standard conditions $\left(1000 \mathrm{~W} / \mathrm{m} 2,25^{\circ} \mathrm{C}\right)$

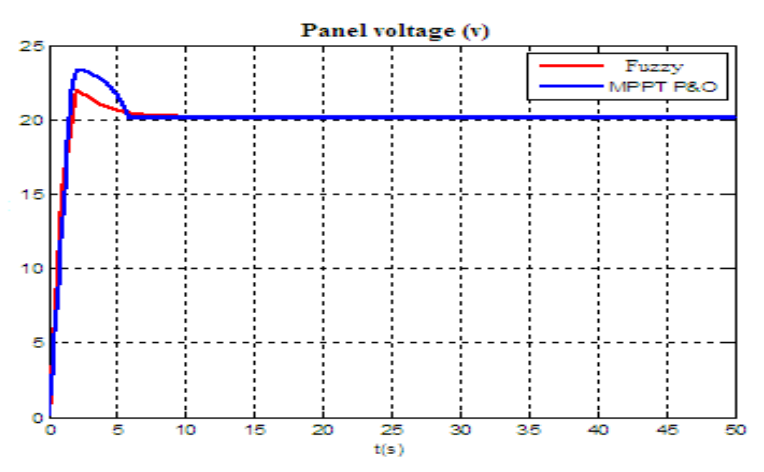

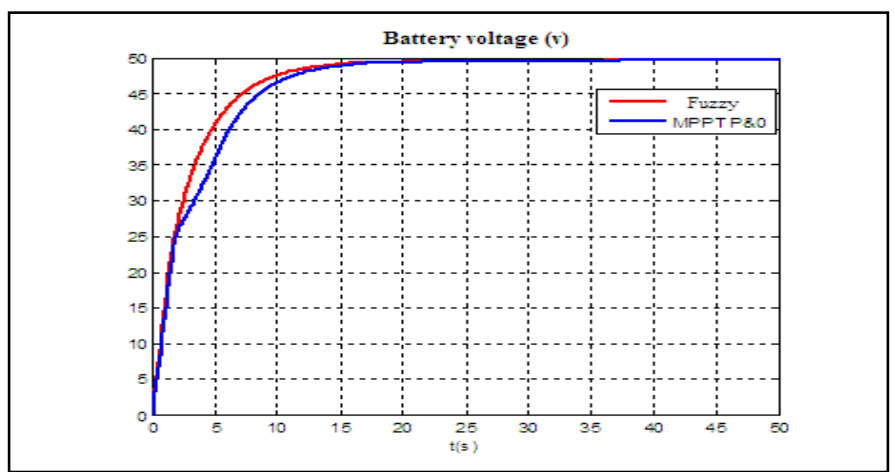

Figure 6. Voltage variation of the module, and battery for both controllers and under standard conditions $\left(1000 \mathrm{~W} / \mathrm{m} 2,25^{\circ} \mathrm{C}\right)$

\section{OPERATION IN VARIABLE CONDITIONS}

To visualize the behavior of our system in real conditions, we vary the illumination and the temperature, as the increment step. These variations allow us to study the robustness of our system.

\section{A. Effet of the illumination variation}

In what follows, we will test the response of the two controllers, for a change in illumination from $1000 \mathrm{~W} / \mathrm{m}^{2}$ to 500 $\mathrm{W} / \mathrm{m}^{2}$, and this in order to confirm any potential performance presented by this command. The results of simulation illustrated in Fig.7 are considered while the temperature is kept constant throughout the simulation interval at $25^{\circ} \mathrm{C}$ [14].
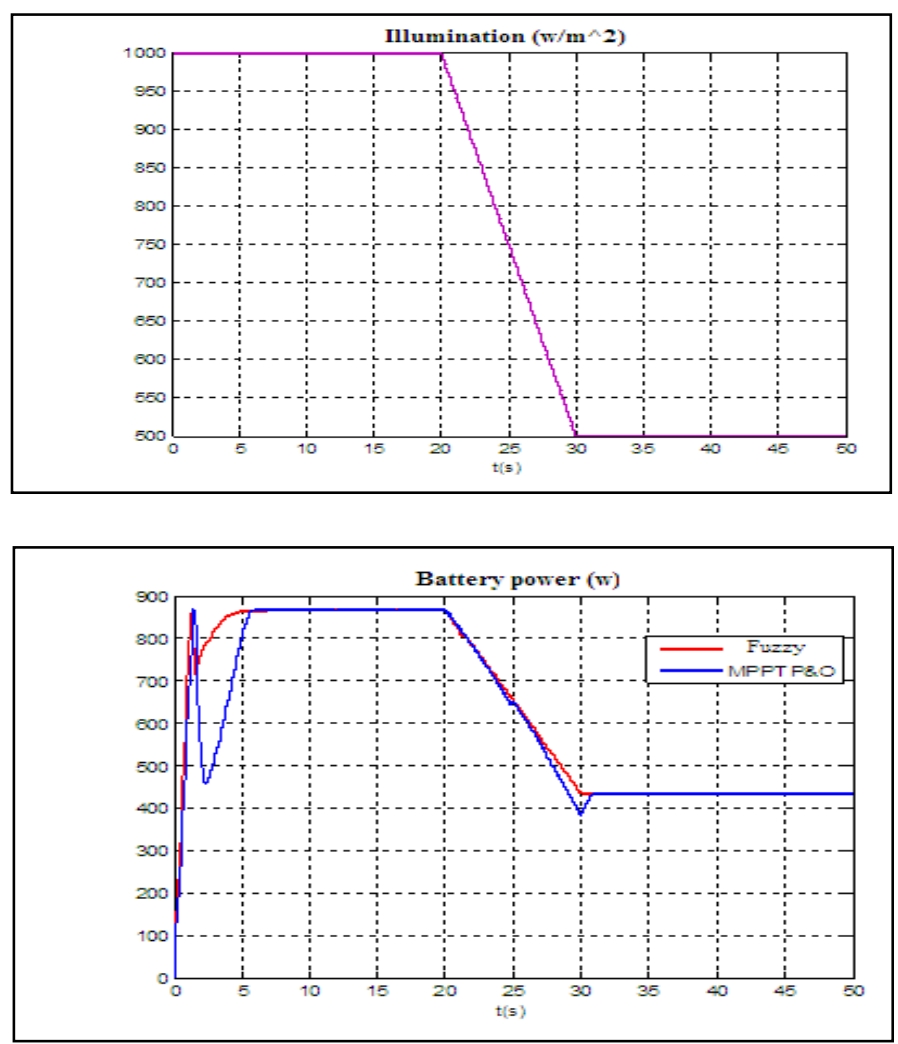

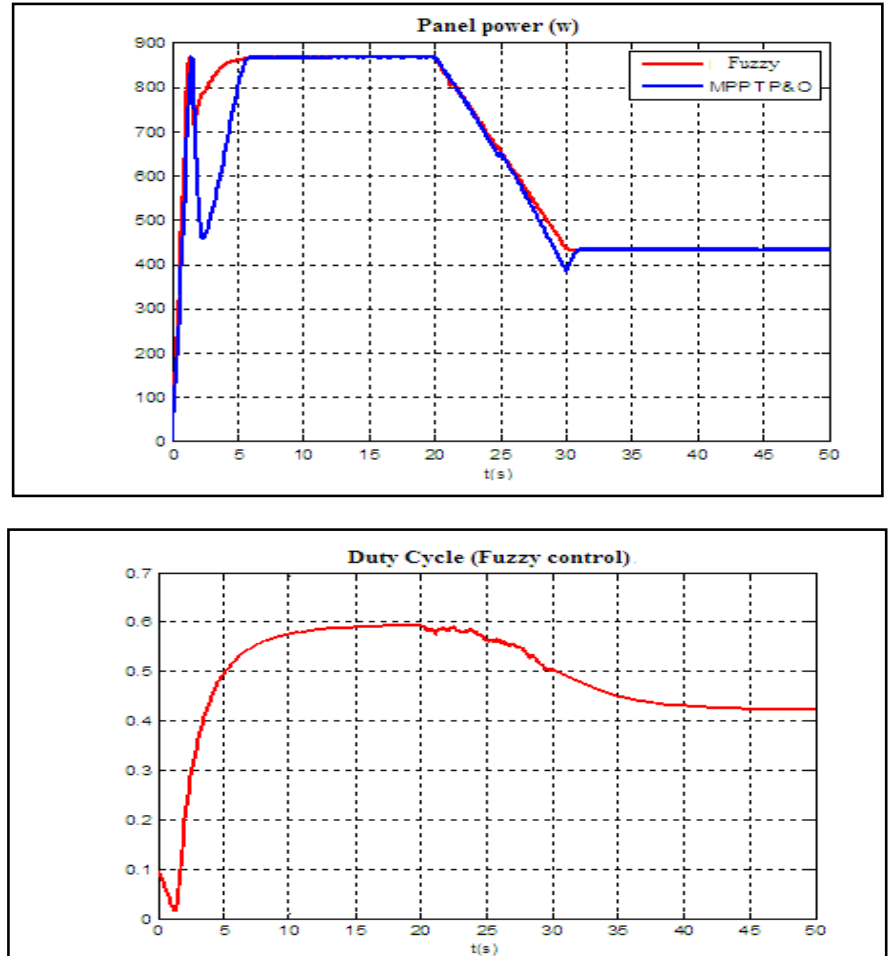

Figure 7. Power variation of the module, and battery and duty cycle D for both controllers for a diminution of the illumination

\section{B. Effect of temperature variation}

It is very important to test the performance of the command, with respect to possible variations in temperature. It is also considered a state variable whose power PV system depends heavily. The parameter of illumination is kept constant at $1000 \mathrm{~W} / \mathrm{m}^{2}$ for control and during the entire simulation time. The temperature increases from $10^{\circ} \mathrm{C}(283 \mathrm{~K})$ to $40^{\circ} \mathrm{C}(313 \mathrm{~K})$ (Fig.8) [14].

\section{Effect of simultaneous variation of illumination and temperature}

Fig.9 shows the simultaneous disruption of weather. An increase of the illumination from $500 \mathrm{~W} / \mathrm{m}^{2}$ to $1000 \mathrm{~W} / \mathrm{m}^{2}$, and temperature from $283 \mathrm{~K}\left(10^{\circ} \mathrm{C}\right)$ to $313 \mathrm{~K}\left(40^{\circ} \mathrm{C}\right)$, with the electrical characteristics of the module and the battery and so the duty cycle [14].

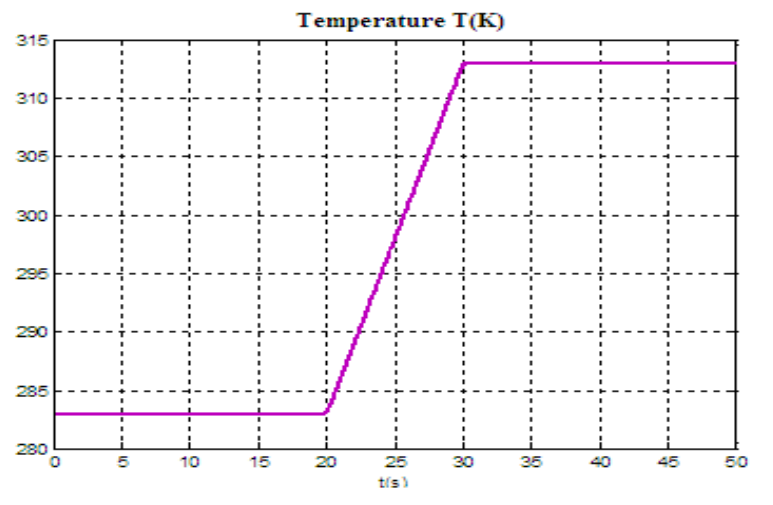

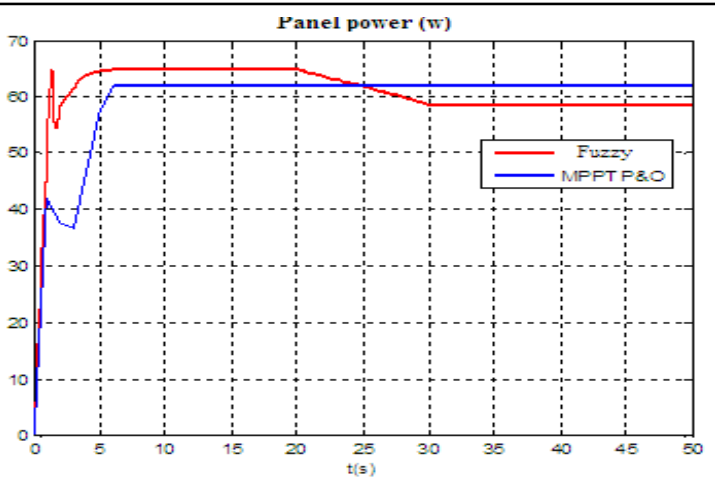
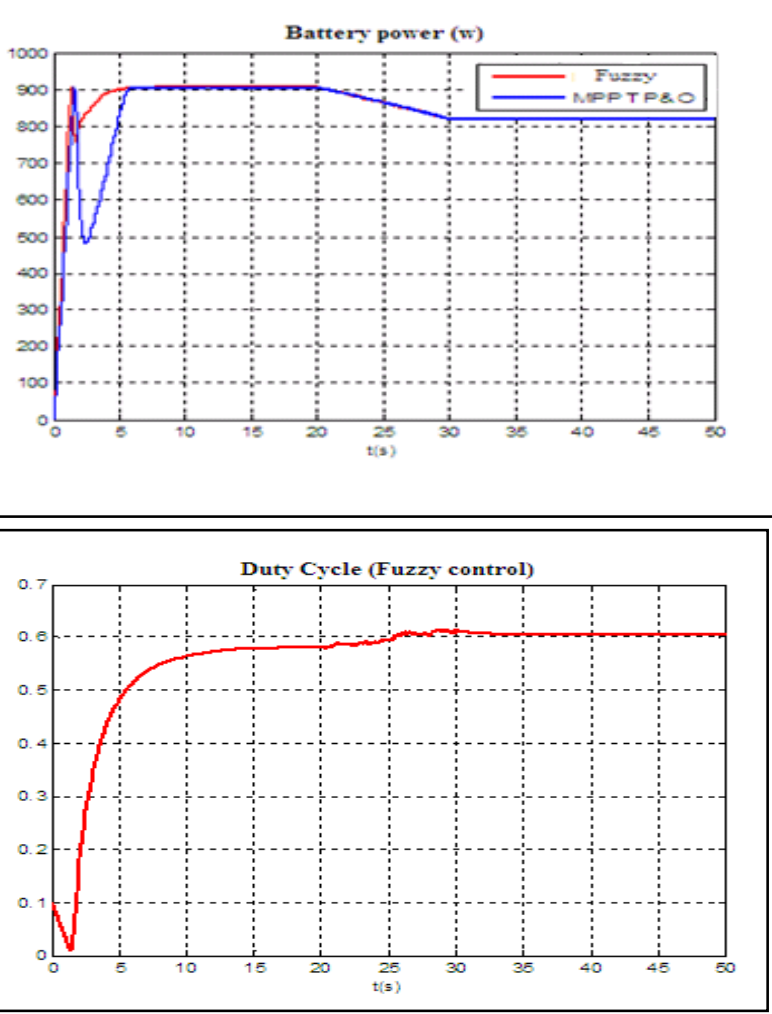

Figure 8. Power variation of the module, and battery and duty cycle D for both controllers for an increase of the temperature

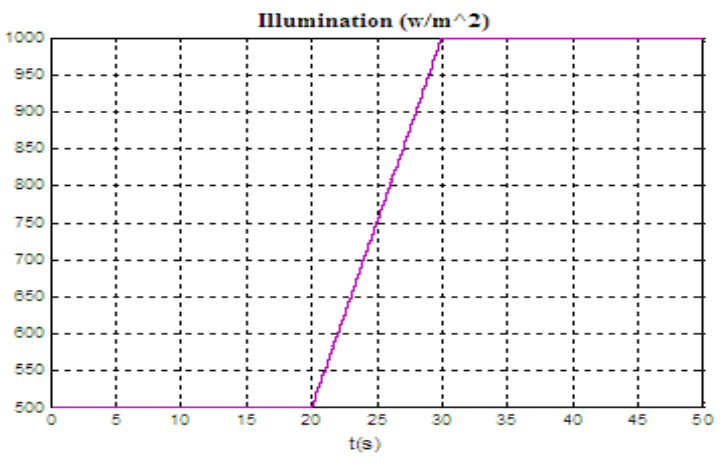



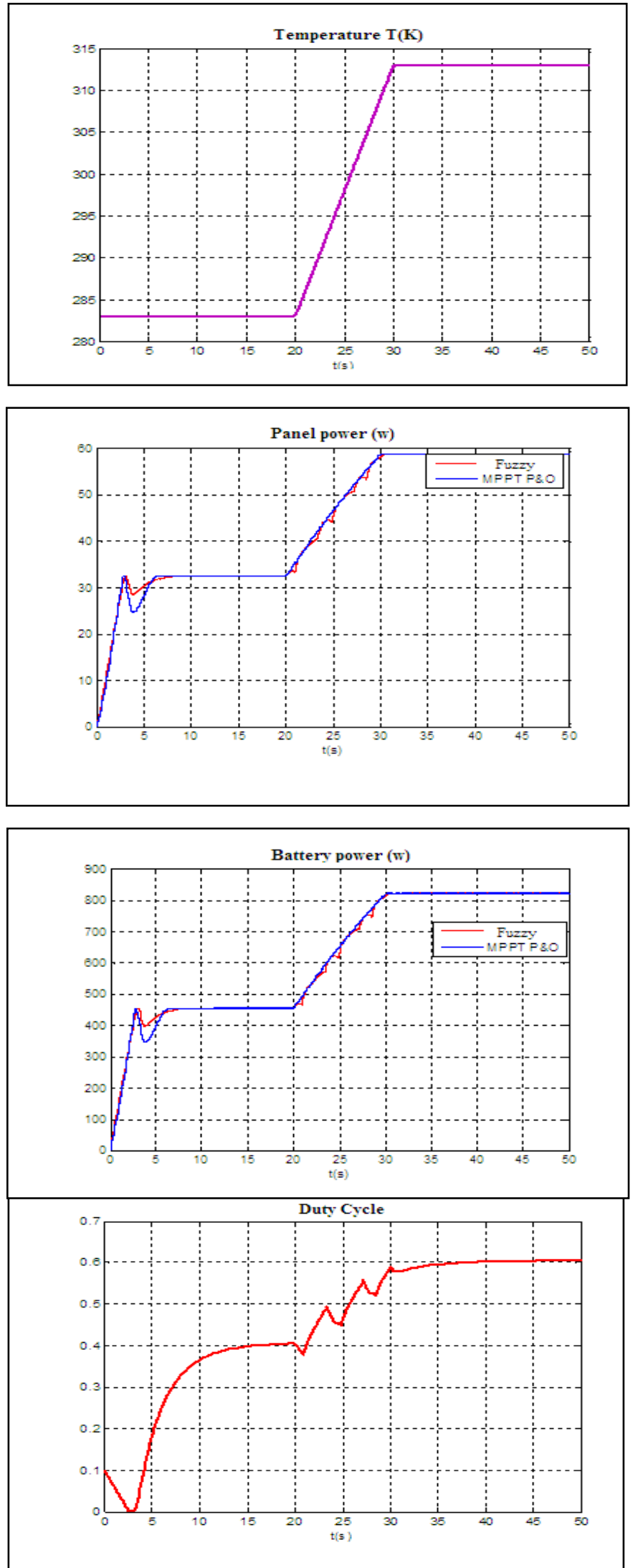

Figure 9. Power variation of the module, and battery and duty cycle D for both controllers for a simultanious increase of illumination and temperature

\section{CONCLUSION}

We have seen in this study in detail the simulation of two methods of control: perturb and observe ( $\mathrm{P} \& \mathrm{O})$ and fuzzy controllers, both of them were applied on a chain of energy conversion supplied by Boost converter. We compared the obtained simulation results, by subjecting the controlled system to the same environmental conditions.

We can conclude that MPPT fuzzy controller, is based on the experience of the operator. It has a very good performance. It improves the responses of the photovoltaic system, it not only reduces the time in response to the continued maximum power point but it also eliminates the fluctuations around this point. The fact that shows the effectiveness of fuzzy controller for photovoltaic systems in standard as in variable environmental conditions. The results obtained for this energy conversion system, show that by using the MPPT fuzzy controller, there is a compromise between rapidity in transient regime and stability in steady state.

These used controllers results can be compared to other methods of control as using neural networks in optimizing the photovoltaic generator power, the idea of our future work as extension of our research to improve more the PV systems yield.

\section{REFERENCES}

[1] A. Chouder, F. Guijoan and S. Silvestre, Simulation of fuzzy-based MPP tracker and performance comparison with perturb \& observe method, Revue des Energies Renouvelables, Vol 11, No 4, pp.577-586, 2008.

[2] C. Cabal and C. Alonso, Adaptive Digital MPPT Control for Photovoltaic Applications, IEEE Trans Power Electronics, pp. 24142419, 2007.

[3] C. L. B. Wu and R. Cheung, Advanced algorithm for MPPT control of photovoltaic systems, Canadian Solar Buildings Conference, Montreal, 2004.

[4] D. Petreuş, C. Fărcaş and I. Ciocan, Modelling and simulation of photovoltaic cells, ACTA TECHNICA NAPOCENSIS- Electronics and Telecommunications, Vol 49, No 1, pp.42-47, 2008.

[5] J. A. Jiang, T. L. Huang, Y. T. Hsiao and C. H. Chen, Tamkang Journal of Science and Engineering, Maximum Power Tracking for Photovoltaic Power Systems, Vol. 8, No 2, pp. 147-153, 2005.

[6] K. Ameur, Étude d'un Système Photovoltaïque Muni d'un Régulateur MPPT : Application à la Conduite d'une Machine Synchrone à Aimants Permanents", Thèse de Magister, ENP, Alger, 2009.

[7] M. A. Elgendy, B. Zahawi and D. J. Atkinson, Assessment of Perturb and Observe MPPT algorithm implementation techniques for PV pumping applications, IEEE transactions on sustainable energy, pp.2133, Vol 3, No 1, 2012.

[8] M. Angel Cid Pastor, Conception et Realisation de Modules Photovoltaiques Electroniques, These de Doctorat de l'Institut National des Sciences Appliquées de Toulouse, Spécialité: Conception des Circuits Microélectroniques et Microsystèmes, 2006.

[9] M. Hatti, Controleur flou pour la poursuite du point de puissance maximum d'un système photovoltaique, Huitieme Conference des Jeunes Chercheurs en Genie Electrique (JCGE'08), Lyon, 2008.

[10] N. Femia, G. Petrone, Giovanni Spagnuolo, and Massimo Vitelli, Optimization of Perturb and Observe Maximum Power Point Tracking Method, Transactions on power electronics, pp.963-973, Vol 20, No 4, 2005.

[11] P. C. M. Bernardo1, Z. M. A. Peixoto1 and L.V. B. Machado Neto, A High Efficient Micro-controlled Buck Converter with Maximum Power Point Tracking for Photovoltaic Systems, International Conference on Renewable Energies and Power Quality (ICREPQ'09), Valencia, 2009. 
[12] R. Faranda and S. Leva, Energy comparison of MPPT techniques for PV Systems, WSEAS transactions on power systems, ISSN: 1790-5060, pp.446-455, Issue 6, Vol 3, 2008.

[13] R. Leyva, C. Alonso, I. Queinnec, A. Cid-pastor, D. Lagrange, 1. Martínez-salamero, (2006), MPPT of photovoltaic systems using
Extremum-Seeking control, pp.249-258, Vol 42, No 1, IEEE transactions on aerospace and electronic systems.

[14] T. Mrabti, M. El Ouariachi, B. Tidhaf et K. Kassmi, (2009), Caractérisation et modélisation fine du fonctionnement électrique des panneaux photovoltaïques, Revue des Energies Renouvelables Vol. 12 No 3, pp.489-500. 